\title{
Immunological analysis of the aqueous humour in candida endophthalmitis. I: Experimental study
}

\author{
F MALECAZE,' M H BESSIERES,' P BEC,' S FLEUTIAUX,' A MATHIS,' \\ AND J P SEGUELA² \\ From the 'Department of Ophthalmology, CHU Rangueil Toulouse (Pr. Bec), and 'Laboratory of \\ Parasitology-Mycology, CHU Rangueil Toulouse (Pr. Seguela), France
}

SUMMARY An immunological study of aqueous humour and serum was carried out in experimental ocular candidosis in rabbits. Anti-candida antibody titres, immunoglobulin $G$, and albumin levels were evaluated in the aqueous humour and in the serum. A local synthesis of anti-candida antibodies was detected in numerous rabbits at the height of clinical activity of the lesions.

In 1954 Goldmann and Witmer' proposed that ocular toxoplasmosis could lead to the intraocular production of antibodies. Subsequent experimental studies have supported their concept of intraocular antibody production." Various investigators have suggested localised specific antibody production in ocular toxocariasis, ${ }^{3}$ in herpes ocular infection, ${ }^{+}$and in acute retinal necrosis. ${ }^{5}$ Our research team questioned whether in candida endophthalmitis an analogous ocular immune response could be detected. We studied anti-candida antibody titres in aqueous humour of rabbits with experimentally induced ocular candidosis.

\section{Materials and methods}

Materials. Fifteen New Zealand white 4-month-old female rabbits were used. A Candida albicans haematogenous endophthalmitis was provoked by the methods described by Edwards et al. ${ }^{\circ} 0 \cdot 1 \mathrm{ml}$ of a suspension of Candida albicans $\left(3 \cdot 1 \times 10^{\circ}\right.$ organisms/ $\mathrm{ml}$, yeast phase, $20 \mathrm{~h}$ culture) in brain heart infusion was injected into the marginal ear vein. The strain was isolated from a vitreous sample of a patient with candida endophthalmitis. A fundus examination was performed daily during the first week, then weekly over a period of two months. This examination was done after maximum dilatation following instillation of phenylephrine and tropicamide, with the indirect ophthalmoscope (Schepens) using the 20 dioptre lens (Nikon). The number of ocular lesions was estab-

Correspondence to Dr F Malecaze, Service d'Ophtalmologie, CHU Toulouse Rangueil, Chemin du Vallon, 31054 Toulouse, France. lished and a qualitative description of the fundus was noted.

Methods. Blood samples and bilateral anterior chamber taps were performed in each rabbit before inoculating the strain, on the 10th day following injection and weekly thereafter until the 42nd day. Aqueous humour aspiration was performed under topical anaesthesia by inserting a 27 gauge needle through the limbus and aspirating approximately $0 \cdot 2 \mathrm{ml}$ of aqueous humour into an insulin syringe. All samples were stored at $-20^{\circ} \mathrm{C}$ until used.

To determine whether an intraocular synthesis occurred it was necessary to evaluate the anticandida antibody titres and the immunoglobulin $\mathrm{G}$ levels in the aqueous humour and in the serum. An albumin measurement was also taken to determine the condition of the blood aqueous barrier.

Serum and aqueous humour anti-candida antibodies were analysed by indirect immunofluorescence according to the Ambroise-Thomas technique. After 48 hours' culture in Sabouraud medium, Candida albicans organisms were used to coat glass slides and were then incubated on the same slides with dilutions of serum or aqueous humour samples (dilutions being continually halved, starting from 1:40 for the sera, and with a pure sample for the aqueous humour). After being washed they were stained with a goat anti-rabbit immunoglobulin fluorescein conjugated antibody (Cappel) diluted to 1:50 with Evans blue for counterstaining. Each test series included a hyperimmune serum for positive control as well as a negative control, both analysed under the same conditions. 
Serum and aqueous humour albumin and immunoglobulin $\mathbf{G}$ concentrations were analysed by laser immunonephelometry (Behring). For the albumin determination $100 \mu \mathrm{l}$ of a $1: 1600$ diluted serum or $1: 10,1: 20,1: 100$ (where necessary) diluted aqueous humour was incubated 15 minutes with $200 \mu \mathrm{l}$ of specific antibody (goat anti-rabbit albumin (Cappel)) 1:6 diluted. For the immunoglobulin $\mathrm{G}$ evaluation $20 \mu \mathrm{l}$ of a 1:160 diluted serum or 1:2, 1:10, 1:100 diluted aqueous humour was incubated for 30 minutes with $200 \mu$ l of a goat anti-rabbit immunoglobulin G (Cappel) 1:6 diluted. In both cases concentrations were determinated by comparison with dilutions of a standard rabbit serum analysed simultaneously under the same experimental conditions.

$C$ coefficient. As the presence of candida antibodies in the aqueous humour could be due either to a transudation of serum antibodies in the anterior chamber through the blood aqueous barrier, or to local synthesis, we calculated the $\mathrm{C}$ coefficient according to a formula derived by Desmonts. ${ }^{8}$

$\mathrm{C}=$ antibody titres $\frac{\text { aqueous humour }}{\text { serum }} \times$ globulin $\mathrm{G} \frac{\text { serum }}{\text { aqueous humour }}$

This coefficient, which compares the immunity quotient of the aqueous humour with that of the serum, enables us to evaluate the local synthesis of specific antibodies. In theory a titre greater than 1 suggests local antibody production within the eye. In interpreting the results we followed Desmonts' formula, ${ }^{\prime}$ considering negative a coefficient less than 2 , significant a $\mathrm{C}$ from 2 to 4 , and positive a $\mathrm{C}$ greater than 4 .

\section{Results}

\section{CLINICAL EVALUATION}

Twelve rabbits of the 15 inoculated developed chorioretinitis, six bilateral, 6 unilateral. The lesions appeared to be identical to those of human candida endophthalmitis. The initial chorioretinal lesions were observed after one week. They were either unique or multiple, white, spherical, small (approximately $1 / 2$ disc diameter) located on the surface of the retina. Three weeks after inoculation the lesions increased in size, and they were accompanied by overlying vitreous haze. After two months there was a massive vitreous exudation and chorioretinal and vitreous cultures were positive.

The control group comprised the six uninfected eyes in the rabbits showing unilateral disease; no lesions were found on ophthalmoscopic examination, and vitreous cultures were negative.

BIOLOGICAL EVALUATION

After completion of the analysis of all aqueous humour and serum samples taken at different dates the results obtained at days 0,10 , and 34 seemed particularly significant.

\section{Rabbits with endophthalmitis}

Day 0 (Table 1): Specific anti-candida antibodies were not detected in the aqueous humour or serum specimens.

Day 10 (Table 2): A significant increase in immunoglobulin $\mathrm{G}$ and albumin was observed in the aqueous humour, accompanied by development of specific antibodies in both serum and aqueous humour. The $\mathrm{C}$ coefficient was significant in only $15 \%$ of cases.

Day 34 (Table 3): Albumin and immunoglobulin G concentrations remained elevated. An increase in specific antibody titres in the serum was noted and more particularly a clear increase of these antibodies in the aqueous humour with a positive $\mathrm{C}$ coefficient in $58 \%$ of cases.

Results from day 17 were comparable to those at day 10 . By day 26 the coefficient was already significant or positive in $40 \%$ of cases.

On day 42 no differences were observed compared to day 34 results.

\section{Control eyes}

Despite the significant increase in specific antibodies in the serum, anti-candida antibody titres in the aqueous humour remained nil or weak, with a $\mathrm{C}$ coefficient less than one in all cases. Albumin and immunoglobulin $G$ levels in the aqueous humour were not modified.

\section{Discussion}

In the controls' eyes numerous cases showed a coefficient of 0 or less than 1 . This finding points to the reproducibility of our tests.

In the affected eyes at the early stages of clinical lesions we found anti-candida antibodies in the aqueous humour in the majority of rabbits. Also noted was a very significant elevation of albumin level in the aqueous humour-indirect evidence of a damaged blood ocular barrier due to inflammation. The negativity of the $\mathrm{C}$ coefficient may be explained by the absence or mere beginning of a local synthesis, or by a masking of local production by a leak of serum antibodies through the blood ocular barrier.

At the height of clinical activity of the lesion a clear increase of anti-candida antibodies is noted in the aqueous humour, resulting in a positive $\mathrm{C}$ coefficient in many cases. In those situations where the $C$ coefficient is negative, the serum reveals a very high titre of specific antibodies, probably masking local production.

Our experimental study enabled us to identify, as 
Table 1 Anti-candida antibodies, immunoglobulin $G$, and albumin detected in serum and aqueous humour of eyes with candida endophthalmitis before inoculation. (1) Antibody titres, (2) expressed as a percentage in relation to standard serum

\begin{tabular}{|c|c|c|c|c|c|c|c|}
\hline & \multicolumn{2}{|c|}{ Anti-candida antibodies (I) } & \multicolumn{2}{|c|}{ Immunoglobulins $G(2)$} & \multicolumn{2}{|c|}{ Albumin (2) } & \multirow[t]{2}{*}{ C coefficient } \\
\hline & $A H$ & Serum & $A H$ & Serum & $A H$ & Serum & \\
\hline Eye 1 & 0 & 0 & 0.3 & 68 & 0.5 & 118 & 0 \\
\hline Eye 2 & 0 & 0 & 0.3 & 80 & $0 \cdot 5$ & 138 & 0 \\
\hline Eye 3 & 0 & () & 0.7 & 65 & $1 \cdot 2$ & 114 & 0 \\
\hline Eye 4 & 0 & () & 0.4 & 78 & 0.7 & 111 & 0 \\
\hline Eye 5 & 0 & 0 & 0.4 & 70 & 0.9 & 109 & 0 \\
\hline Eye 6 & 0 & 0 & 0.3 & 60 & 0.8 & 126 & 0 \\
\hline Eye 7 & 0 & () & 0.3 & 96 & 0.8 & 135 & 0 \\
\hline Eye 8 & 0 & 0) & 0.1 & 96 & 0.9 & 135 & 0 \\
\hline Eye 9 & 0 & () & 0.1 & 101 & $1 \cdot 1$ & 133 & 0 \\
\hline Eye 10 & 0 & 0 & $(0 \cdot 1$ & 101 & 0.9 & 133 & 0 \\
\hline Eye 11 & 0 & 0 & 0.8 & 100 & 0.9 & 111 & 0 \\
\hline Eye 12 & 0 & 0 & 0.9 & 100 & $1 \cdot 1$ & 111 & 0 \\
\hline
\end{tabular}

$\mathrm{AH}=$ aqueous humour.

Table 2 Anti-candida antibodies, immunoglobulin $G$, and albumin detected in serum and aqueous humour of eyes with candida endophthalmitis 10 days after inoculation. (1) Antibody titres, (2) expressed as a percentage in relation to standard serum

\begin{tabular}{|c|c|c|c|c|c|c|c|}
\hline & \multicolumn{2}{|c|}{ Anti-candida antibodies (I) } & \multicolumn{2}{|c|}{ Immunoglobulins $G(2)$} & \multicolumn{2}{|c|}{ Albumin (2) } & \multirow[t]{2}{*}{ C coefficient } \\
\hline & $A H$ & Serum & $A H$ & Serum & $A H$ & Serum & \\
\hline Eye 1 & 4 & 40 & 18 & 70 & 29 & 109 & $0 \cdot 34$ \\
\hline Eye 2 & 4 & 40 & 19 & 78 & 37 & 124 & $0 \cdot 8$ \\
\hline Eye 3 & 16 & 320 & 3 & 77 & 6 & 110 & 1 \\
\hline Eye 4 & 2 & 80 & 11 & 80 & 28 & 118 & $0 \cdot 18$ \\
\hline Eye 5 & 64 & 640 & 12 & 70 & 24 & 114 & 0.6 \\
\hline Eye 6 & 32 & 640 & $3 \cdot 4$ & 68 & $6 \cdot 2$ & 126 & 1 \\
\hline Eye 7 & 2 & 40 & $1 \cdot 5$ & 96 & $2 \cdot 6$ & 126 & 3 \\
\hline Eye 8 & 2 & 40 & $1 \cdot 3$ & 96 & 1.9 & 126 & 3.7 \\
\hline Eye 9 & 1 & 40 & 5 & 91 & 10 & 108 & 0.4 \\
\hline Eye 10 & 1 & 40 & $2 \cdot 7$ & 91 & $4 \cdot 3$ & 108 & 0.8 \\
\hline Eye 11 & 40 & 40 & 58 & 93 & 75 & 100 & $1 \cdot 6$ \\
\hline Eye 12 & 40 & 40 & 45 & 93 & 82 & 100 & 2 \\
\hline
\end{tabular}

$\mathrm{AH}=$ aqueous humour.

Table 3 Anti-candida antibodies, immunoglobulin $G$, and albumin detected in serum and aqueous humour of eyes with candida endophthalmitis 34 days after inoculation. (1) Antibody titres, (2) expressed as a percentage in relation to standard serum

\begin{tabular}{|c|c|c|c|c|c|c|c|}
\hline & \multicolumn{2}{|c|}{ Anti-candida antibodies (1) } & \multicolumn{2}{|c|}{ Immunoglobulins $G(2)$} & \multicolumn{2}{|c|}{ Albumin (2) } & \multirow[t]{2}{*}{ Ccoefficient } \\
\hline & $A H$ & Serum & $A H$ & Serum & $A H$ & Serum & \\
\hline Eye 1 & 128 & 320 & 6 & 75 & 12 & 114 & $4 \cdot 8$ \\
\hline Eye 2 & 8 & 160 & 2 & 86 & 4 & 131 & 2 \\
\hline Eye 3 & 128 & 320 & $5 \cdot 5$ & 77 & 8 & 111 & 7 \\
\hline Eye 4 & 320 & 160 & 34 & 83 & 74 & 108 & $4 \cdot 8$ \\
\hline Eye 5 & 64 & 640 & 9 & 81 & 13 & 116 & 1 \\
\hline Eye 6 & 64 & 640 & 13 & 63 & 24 & 93 & 0.5 \\
\hline Eye 7 & 64 & 160 & $7 \cdot 5$ & 90 & 13 & 113 & $4 \cdot 8$ \\
\hline Eye 8 & 64 & 160 & $6 \cdot 6$ & 91 & 12 & 113 & $5 \cdot 5$ \\
\hline Eye 9 & 64 & 640 & $6 \cdot 4$ & 85 & 11 & 126 & $1 \cdot 3$ \\
\hline Eye 10 & 32 & 640 & $3 \cdot 7$ & 85 & $5 \cdot 6$ & 126 & 1 \\
\hline Eye 11 & 640 & 80 & 59 & 87 & 90 & 107 & $11 \cdot 8$ \\
\hline Eye 12 & 320 & 80 & 44 & 87 & 87 & 107 & 7.9 \\
\hline
\end{tabular}

$\mathrm{AH}=$ aqueous humour . 
in ocular toxoplasmosis, a local synthesis of specific antibodies in cases of candida chorioretinitis. This production may be observed only a few days after the onset of the clinical lesions. Another interesting finding is the significant damage to the blood ocular barrier. These results have led us to believe that an anterior chamber tap could be used as a diagnostic procedure in human candida endophthalmitis.

\section{References}

1 Goldmann H, Witmer R. Antikörper in kammerwasser. Ophthalmologica 1954; 127: 232-330.

2 Silverstein AM. Doyne memorial lecture 1974. Immunogenic uveitis. Trans Ophthalmol Soc UK 1974; 94: 496-516.

3 Felberg NT, Shields JA, Federman JL. Antibody to Toxocara canis in the aqueous humour. Arch Ophthalmol 1981; 99: 1563-4.
4 Denis J, Rossignol A, Langlois M, Dorey C, Aymard M, Giraud JP. Valeur du coefficient de charge immunitaire des globulines de l'humeur aqueuse au cours de l'herpès oculaire. J Fr Ophtalmol 1981: 4: 173 .

5 Sarkies N, Gregor Z, Forsey T. Darougar S. Antibodies to herpes simplex virus type I intraocular fluids of patients with acute retinal necrosis. BrJ Ophthalmol 1986; 70: 81-4.

6 Edwards JE, Montgmerie JZ, Foos RY, Shaw K. Guze LB. Experimental hematogenous endophthalmitis caused by Candida albicans. J Infect Dis 1975; 131: 649-57.

7 Ambroise-Thomas P. Immunofluorescence indirecte. In: Golvan $\mathrm{Y}$, Ambroise-Thomas $\mathrm{P}$, eds. Nouvelles techniques en parasitologie. Paris: Flammarion, 1984: 181-4.

8 Desmonts G. Definite serological diagnosis of ocular toxoplasmosis. Arch Ophthalmol 1966; 76: 839-51.

9 Desmonts G. Toxoplasmose oculaire. Etude épidemiologique. Bilan de 2030 examens d'humeur aqueuse. Arch Ophtalmol (Paris) 1973; 83: 87-102.

Accepted for publication 29 January 1987. 